\title{
Post-grazing residue control, season and forage characteristics of tropical pastures grazed by goats and ewes in Guadeloupe (FWI) ${ }^{1,2}$
}

\author{
Eusebio Ortega-Jiménez $z^{3}$, Gisèle Alexandre ${ }^{3,4}$, Ode Coppry ${ }^{3}$, \\ Georges Saminadin ${ }^{3}$, Pablo Cruz $z^{5}$ and Alain Xandé ${ }^{3}$
}

J. Agric. Univ. P.R. 90(1-2):37-56 (2006)

\begin{abstract}
Creole goats (G) and Martinik sheep (S) were reared on rotationally grazed tropical pastures to test the effect of post-grazing residue control on forage production, and morphological and chemical composition. A system in which residuals were mown (RM) was compared to the control system (RR) during three seasons (dry, intermediate and rainy) over one year. Mean weight of herbage mass at the beginning of the grazing periods differed among treatments, 3,123 vs. $5,010 \mathrm{~kg}$ DM/ha in GRM and GRR plots, and 2,538 vs. $3,753 \mathrm{~kg}$ DM/ha in SRM and SRR plots, respectively. The sward structure was improved in the RM systems. A higher leaf proportion $(42 \%$ vs. $36 \%$ ), a similar stem proportion (around $43 \%$ ), and a lower debris proportion (15\% vs. $19 \%$ ) were noted in GRM. In the SRM and SRR plots, corresponding values were for leaves $46 \%$ vs. $36 \%$; stems, $36 \%$; and debris, $17 \%$ vs. $20 \%$. The $29 \%$ difference in herbage accumulation in favor of goat over sheep pastures appears to be related to their higher nitrogen nutrition index (82 vs. 60\%, respectively). Seasonal effects were discussed. Chemical composition of the forage did not differ between treatments or among seasons. The crude protein content reached 115 and $90 \mathrm{~g} / \mathrm{kg}$ DM before grazing and 85 and $65 \mathrm{~g} / \mathrm{kg}$ DM after grazing in goat and sheep plots, respectively. Forage characteristics did not limit kid and lamb growth, and the average daily live weight gain did not differ between treatments. It is recommended that the post-grazing forage residues be consumed by associated herbivores to achieve the same effect as mowing in a more practical way.
\end{abstract}

Key words: post-grazing residues, biomass, chemical composition, goat, sheep, tropical pastures

Manuscript submitted to Editorial Board 1 July 2003.

${ }^{2}$ We gratefully acknowledge the support of R. Arquet, P. Mulciba, A. Nepos and W. Troupe during the field work, and the help of S. Calif and C. Baptistin with laboratory analyses. We also wish to thank H. Archimède, G. Garcia and M. Mahieu for their comments on the improvement of the manuscript. This study has been supported by the "Region Guadeloupe" and the "European Community" (FEOGA). The first author is grateful to CONACYT, ANUIES and Colegio de Postgraduados de Mexico.

'Unité de Recherches Zootechniques, INRA Antilles-Guyane, Domaine Duclos-Prise d'Eau, 97170 Petit-Bourg, Guadeloupe, French West Indies.

${ }^{4}$ Author to whom correspondence should be addressed; e-mail: aexandre@antilles.inra.fr

'Unité d'Agronomie, INRA, BP 27, 31326 Castanet-Tolosan, France. 


\section{RESUMEN}

Control de residuos después del pastoreo, la estación y las características de forrajes tropicales pastoreados por cabras y ovejas en Guadalupe (FWI)

Se mantuvieron cabras "Creole" (G) y ovejas "Martinik" (S) en praderas tropicales en un sistema rotacional para probar el efecto del control del forraje residual después del pastoreo sobre la producción y la composición morfológica y química del forraje. Un sistema mecánico de corte de forraje residual y su remoción (RM) se comparó con un sistema testigo (RR) durante tres estaciones (seca, intermedia y lluviosa) en un año completo. El peso de biomasa al inicio de los periodos de pastoreo difirió entre tratamientos: 3,123 vs. $5,010 \mathrm{~kg}$ MS/ha en parcelas de GRM y GRR, y 2,538 vs. $3,753 \mathrm{~kg}$ MS/ha en las de SRM y SRR, respectivamente. La estructura vegetal fue mejorada en los sistemas RM. Se determinó una mayor proporción de hojas $(42 \%$ vs. $36 \%$ ), similar proporción de tallos (cerca de $43 \%$ ), y menor proporción de material muerto $(15 \%$ vs. $19 \%)$ en GRM vs. GRR. En las parcelas SRM y SRR, los valores correspondientes de hojas fueron $46 \%$ vs. $36 \%$; tallos, $36 \%$; y material muerto, $17 \%$ vs. $20 \%$, respectivamente. Es probable que la diferencia de $29 \%$ mayor en acumulación de forraje en las praderas de cabras sobre las de ovejas se relacione a su más alto índice nutritivo de nitrógeno ( 82 vs. $60 \%$ ). Los efectos estacionales fueron discutidos. La composición química del forraje no difirió entre tratamientos y estaciones. El contenido de proteína cruda obtenida fue de 115 y $85 \mathrm{~g} / \mathrm{kg}$ MS y de 90 y $65 \mathrm{~g} /$ kg MS antes y después del pastoreo en las parcelas de cabras y ovejas, respectivamente. Las características del forraje no limitaron el crecimiento de los cabritos y corderos, y la ganancia diaria de peso no difirió entre tratamientos. Se recomienda explotar el forraje residual con herbívoros asociados con miras a lograr un manejo práctico al del residuo removido.

Palabras clave: residuos de pastoreo, biomasa, cabras, ovejas, pastos tropicales

\section{INTRODUCTION}

In the Caribbean and Latin American regions the most widespread animal production system is grazing, and more than $70 \%$ of the agricultural area is dedicated to the production of herbivores (FAO, 2001). Slightly intensified systems are the norm, as the average stocking rate calculated was close to $1.77 \mathrm{ha} /$ animal unit. Under these systems, inadequate grazing management combined with tropical forage physiology leads to low animal output (Minson, 1990; Humphreys, 1991). Tropical forages present high contents of structural elements that are poorly digestible and lead to low or medium nutritive values (Aumont et al., 1995). However, adequate management of tropical pastures harvested at the right stage of maturity may improve nutritive value (Aumont et al., 1995; Archimède et al., 2000). Tropical pastures are productive but season-dependent (Salette and Chenost, 1971; Crespo, 1985); thus adequate levels of fertilization and irrigation allow high accumulation of forage biomass throughout the year. The intensive utilization of forages is one way of increasing the production of ruminants in tropical areas. Use of semi-intensive management systems may increase production 
from pastures in situations where land and energy-dense feeds are limited (CIAT, 1985; Humphreys, 1991). In the French West Indies, intensive grazing systems (artificial pastures, high level of fertilization and irrigation) were investigated with small ruminants. They produced high animal output per unit area, [up to $1,385 \mathrm{~kg}$ live weight (LW) weaned kids per hectare and per year (Alexandre et al., 1997) and $1,250 \mathrm{~kg}$ LW weaned lambs (Mahieu et al., 1997)]. Such systems are of interest as a means of coping with the continuing reduced land availability; however, some disadvantages have been reported. On the one hand, the large amounts of herbage are not totally exploited, especially with small ruminants because of their selective feeding behavior (Baumont et al., 2000). On the other hand, the use of high levels of nitrogen fertilization greatly affects stolon elongation in stoloniferous species such as Digitaria decumbens (Cruz et al., 1989) resulting in a high stolon fraction and a low leaf/stem ratio, 0.67, for swards grazed by suckling goats (Alexandre et al., 1997) or 0.96, for swards grazed by suckling ewes (Mahieu et al., 2002). This condition leads to long-term bad management of the pastures and consequently to weed invasion and reduced forage value.

The challenge then is to maintain a high level of productivity from these systems while reducing their negative component. Better use of the available forage could be achieved via a higher grazing pressure. However, it is not recommended to increase the stocking rate of small ruminants at pasture because of the high risk of internal parasites under these grazing systems (Aumont et al., 1997). Some authors have tested different methods of controlling the high post-grazing forage residues through the use of herbicides, fire or slashing (Humphreys, 1991; Phillips and Campbell, 1998; Cardoso et al., 2001; Heringer and Jacques, 2001). Our aim at INRA is to exploit the fodder resources available locally; thus new systems, including combined grazing with different herbivores, have been investigated (Mahieu et al., 1997; 2002). Experiments to study the management of such residues were designed, and cutting and removing post-grazing forage residues was initially tested with both goats and sheep under rotational pasture management. The aim of the present experiment was to investigate intensive grazing systems for small ruminant production by varying pasture management (elimination of residues) and season of animal production. To develop management approaches for harvesting highquality forage and to optimize the use of forages in animal feeding require an understanding not only of forage production, but also of plant composition and changes in nutritive value. Therefore, the evaluations were based on herbage characteristics at the start and the end of the grazing period. 


\section{MATERIALS AND METHODS}

This study was carried out at the Animal Production Unit of the INRA Research Centre in Guadeloupe, which is a humid tropical island within the Caribbean $\left(16^{\circ} 1^{\prime} \mathrm{N}, 61^{\circ} 6^{\prime} \mathrm{W}\right)$. The experimental farm in question is located in the driest area of the island, where annual rainfall averages $1,280 \mathrm{~mm}$, with a dry season lasting from January to May, during which time precipitation is less than $70 \mathrm{~mm}$ per month. Absolute maximum air temperature varies from $27^{\circ} \mathrm{C}$ (January) to $32^{\circ} \mathrm{C}$ (August) and absolute minimum from 21 to $25^{\circ} \mathrm{C}$, respectively. The relative humidity is usually above $70 \%$ and the day length ranges from 11 to $13 \mathrm{~h}$.

Two concurrent experiments with Creole goat (G) and Martinik sheep (S) on tropical forage swards were conducted and analyzed separately. For both small ruminant species, two plots of a pasture based on tropical grasses were compared with regard to sward management. Pastures were rotationally grazed on a 28-day regrowth cycle all year round. Two methods of pasture management were tested: In the first, when the animals were moved out of the paddock, the sward was mown and the post-grazing residues were removed; this system was called "residuals mown" (RM) and was compared to the control system in which residuals were not mown and remained in place (RR). These treatments were defined as GRM vs. GRR (in goats) and SRM vs. SRR (in sheep), respectively. Each plot was grazed by 20 females (half lactating and half pregnant). The experiment lasted for one year, and the two pasture management methods were compared on the basis of lactations that took place during three seasons.

The mean liveweight (LW) ( \pm s.d.) for goats were $35.5 \pm 1.8 \mathrm{~kg}$ vs. 36.6 $\pm 2.9 \mathrm{~kg}$ for the GRM and GRR groups, respectively; for ewes $47.4 \pm 2.9 \mathrm{~kg}$ and $46.2 \pm 2.4 \mathrm{~kg}$ for the SRM and SRR groups, respectively. The animals were managed to obtain three parturitions within a two-year mating system. The male effect was systematically used for insuring ovulatory and estrus activities. The birth periods occurred during the dry season (DS), February; the intermediate season (IS), June; and the rainy season (RS), October. The offspring were weaned between 10 and 12 weeks of age. Every two weeks spraying was done for tick control, and anthelminthic drenchings were carried out. Kids and lambs were weighed at birth, then every week and at weaning. Does and ewes were weighed every week.

Prior to the experiment, pastures were mown to $5 \mathrm{~cm}$ above ground, divided into two plots, and then each plot was grazed under its respective management during a two-month period. Thereafter pastures were grazed after every 28-day regrowth period for a full year. Each goat plot of $4,100 \mathrm{~m}^{2}$ was divided into five paddocks and the animals grazed the forage within each paddock for seven days per cycle. The 
same design was carried out with sheep over a total area of $6,250 \mathrm{~m}^{2}$ per management method. The pastures were irrigated and fertilized annually with $150 \mathrm{~kg}$ nitrogen/ha proportionally applied after each grazing period as 30-12-18 fertilizer. In the RM system, all the postgrazing residues were mown with a lawnmower fitted with a grass collector. The main sward components were determined at the beginning of the experiment [method adapted from Daget and Poissonet (1971)]; species were identified by using Fournet (1978). These species had good pastoral value: Digitaria decumbens, Panicum maximum, Brachiaria mutica, Dichantium sp., representing $95 \%$ of the whole sward for the goat plots and $90 \%$ for the ewe plots. Species of low pastoral value, Cynodon dactylon, Abilgaardia sp., Eleusine indica, miscellanous Cyperaceae represented five to $10 \%$.

Biomass and chemical composition of the herbage were determined at the start and at the end of the grazing periods twice during each season of production. Herbage mass was estimated by cutting a $0.09-\mathrm{m}^{2}$ area with hand-held electric clippers in ten different places of the paddock. Samples were weighed fresh, and a sub-sample of $300 \mathrm{~g}$ was kept to determine herbage DM content (drying to constant weight at $60^{\circ} \mathrm{C}$ in a forced draft oven for $48 \mathrm{~h}$ ). The chemical composition of the samples was determined according to the methods of Van Soest et al. (1991) for fibrous fractions [Acid Detergent Fiber (ADF), Neutral Detergent Fiber (NDF) and Acid Detergent Lignin (ADL)], and by the Dumas method for crude protein $(\mathrm{CP})$. The nitrogen nutrition index (NNI) of each plot was determined as proposed by Cruz and Lemaire (1995) for C4 plant species.

Herbage data were analyzed by using SAS general linear model (1989), separately for each small ruminant species. The model contains effects due to pasture management, birth season (DS, IS and RS) and pasture management $\times$ birth season interaction. The model was as follows:

$$
\mathrm{Y}_{\mathrm{ij}}=\mathbf{m}+\mathrm{PM}_{\mathrm{i}}+\mathrm{S}_{\mathrm{j}}+(\mathrm{PMS})_{\mathrm{ij}}+\mathrm{e}_{\mathrm{ij}}
$$

Where $m$ is the mean;

$\mathrm{PM}_{\mathrm{i}}$ is the pasture management effect $(\mathrm{i}=1,2)$;

$\mathrm{S}_{\mathrm{j}}$ is the season effect $(\mathrm{j}=1,2,3)$;

$\mathrm{PMS}_{\mathrm{ij}}$ is the pasture management * birth season interaction and

$\mathrm{e}_{\mathrm{ij}}$ is the residual term.

The average daily gain (ADG) data were analyzed by using the same model with the addition of the effects of litter size and sex and birth weight as covariables. 


\section{RESULTS}

Tables 1 and 2 show herbage height, DM content and herbage mass before and after the grazing period for the goat and sheep plots, respectively. At the beginning of the grazing period, the herbage mass was estimated at 3,123 vs. $5,010 \mathrm{~kg} \mathrm{DM} / \mathrm{ha}(\mathrm{P}<0.001)$ in GRM and GRR plots, respectively; corresponding values for SRM and SRR plots were 2,538 vs. $3,753 \mathrm{~kg} \mathrm{DM} / \mathrm{ha}(\mathrm{P}<0.001)$. Independant of small ruminant species, there was no seasonal effect upon the herbage mass in the system where herbage residues were mown, whereas this variable differed among seasons in the control system. A lower $(\mathrm{P}<0.05)$ forage accumulation was observed during the dry season than during the other two seasons. For either sward management, taller $(\mathrm{P}<0.05)$ herbage heights and lower $(\mathrm{P}<0.01) \mathrm{DM}$ contents were observed during the rainy season. When animals moved out of the paddock, the herbage masses remaining were 2,052 vs. $3,630 \mathrm{~kg} \mathrm{DM} / \mathrm{ha}(\mathrm{P}<0.01)$ in GRM and GRR plots and 1,653 vs. $3,240 \mathrm{~kg}$ DM/ha $(\mathrm{P}<0.01)$ in SRM and SRR plots. The same effect of season was noted as for the initial herbage availability.

For the goat groups (Table 1), forage offered to the animals at the beginning of the grazing cycles was characterized by a higher $(\mathrm{P}<0.05)$ leaf proportion in the RM system than in the RR (42\% vs. $36 \%$ ), in combination with a similar stem proportion (around $43 \%)$ and a lower $(\mathrm{P}<$ 0.05 ) debris proportion ( $15 \%$ vs. $19 \%$ ), respectively. In sheep plots (Table 2), the same effects were observed with the corresponding values for proportions of leaves (46\% vs. $36 \%$; $\mathrm{P}<0.05)$, stems $(36 \%)$ and debris $(17 \%$ vs. $20 \% ; \mathrm{P}<0.05)$, respectively. The leaf to stem ratios of the herbage at the beginning of the grazing period were higher $(\mathrm{P}<0.05)$ in the RM system than in the control, 1.04 vs. 0.85 in goat plots and 1.24 vs. 1.08 in the sheep plots, respectively. At the end of the grazing period, the herbage remaining in the paddock was composed of $50 \%$ vs. $44 \%$ of stems in the GRM and GRR plots and $44 \%$ vs. $42 \%$ in the SRM and SRR plots, respectively. For the different groups, the dead material proportion reached about $38 \%$. Seasonal effects were observed in these variables (Tables 1 and 2).

The CP, NDF, ADF and ADL contents of the forage at the beginning and at the end of the grazing period did not differ $(\mathrm{P}>0.05)$ between treatment and season (Tables 3 and 4). Values for CP content reached 120 vs. $110 \mathrm{~g} / \mathrm{kg}$ DM before grazing and 92 vs. $81 \mathrm{~g} / \mathrm{kg} \mathrm{DM}(\mathrm{P}>0.05)$ after grazing for GRM and GRR plots. Corresponding values for the sheep plots were 99 vs. $85 \mathrm{~g} / \mathrm{kg} \mathrm{DM}(\mathrm{P}>0.05)$ and $77 \mathrm{vs} .61 \mathrm{~g} / \mathrm{kg} \mathrm{DM}$ $(\mathrm{P}>0.05)$ for SRM and SRR plots, respectively. The mean contents of forage NDF and ADF were around 720 and $360 \mathrm{~g} / \mathrm{kg}$ DM, respectively, regardless of the type of plot. 
TABLE 1. Herbage characteristics at the start and end of each grazing period of rotationally grazed tropical pastures for suckling Creole goats $(G)$ in Guadeloupe according to pasture management, refusals mown (RM) vs. refusals remained (RR) and birth season.

\begin{tabular}{|c|c|c|c|c|c|c|c|c|}
\hline \multirow{2}{*}{$\begin{array}{l}\text { Season } \\
\text { Pasture management }\end{array}$} & \multicolumn{2}{|c|}{ Dry season } & \multicolumn{2}{|c|}{ Intermediate season } & \multicolumn{2}{|c|}{ Rainy season } & \multicolumn{2}{|c|}{ Seasonal effect } \\
\hline & GRM & GRR & GRM & GRR & GRM & GRR & GRM & GRR \\
\hline \multicolumn{9}{|c|}{ Herbage characteristics at the start of the grazing period } \\
\hline Pasture height (mm) & $101.30 \mathrm{a}^{1}$ & $155.60 \mathrm{~b}$ & $87.90 \mathrm{a}$ & $182.40 \mathrm{~b}$ & 161.10 & 152.50 & $* * 2$ & $* *$ \\
\hline Dry matter content $(\%)$ & 21.00 & 23.40 & 21.10 & 21.80 & 16.60 & 19.80 & * & NS \\
\hline Herbage mass (t DM/ha $)^{3}$ & $3.00 \mathrm{a}$ & $4.42 \mathrm{~b}$ & $3.28 \mathrm{a}$ & $5.83 \mathrm{~b}$ & $3.09 \mathrm{a}$ & $4.78 \mathrm{~b}$ & NS & $* *$ \\
\hline Leaf mass (t DM/ha) & $1.10 \mathrm{a}$ & $1.93 \mathrm{~b}$ & $1.05 \mathrm{a}$ & $1.58 \mathrm{~b}$ & 1.48 & 1.61 & $*$ & $\% *$ \\
\hline Stem mass (t DM/ha) & 0.98 a & $1.63 \mathrm{~b}$ & $1.64 \mathrm{a}$ & $2.58 \mathrm{~b}$ & $1.09 \mathrm{a}$ & $2.17 \mathrm{~b}$ & ** & $* *$ \\
\hline Debris mass ( $\mathrm{t} \mathrm{DM} / \mathrm{ha}$ ) & $0.54 \mathrm{a}$ & $0.72 \mathrm{~b}$ & $0.59 \mathrm{a}$ & $1.36 \mathrm{~b}$ & $0.33 \mathrm{a}$ & $0.94 \mathrm{~b}$ & $*$ & $* *$ \\
\hline Leaf/stem ratio & 1.13 & 1.18 & 0.63 & 0.61 & $1.36 \mathrm{a}$ & $0.74 \mathrm{~b}$ & $* *$ & $* *$ \\
\hline \multicolumn{9}{|c|}{ Herbage characteristics at the end of the grazing period } \\
\hline Pasture height (mm) & 61.40 & 54.90 & $67.30 \mathrm{a}$ & $93.30 \mathrm{~b}$ & $61.20 \mathrm{a}$ & $72.90 \mathrm{~b}$ & NS & $*$ \\
\hline Herbage mass (t DM/ha) & $1.88 \mathrm{a}$ & $2.78 \mathrm{~b}$ & $2.25 \mathrm{a}$ & $4.88 \mathrm{~b}$ & $2.02 \mathrm{a}$ & $3.24 \mathrm{~b}$ & $* *$ & $* *$ \\
\hline Leaf mass ( $\mathrm{t}$ DM/ha) & $0.28 \mathrm{a}$ & $0.43 \mathrm{~b}$ & $0.24 \mathrm{a}$ & $0.53 \mathrm{~b}$ & 0.54 & 0.50 & $* *$ & NS \\
\hline Debris mass ( $\mathrm{t} \mathrm{DM} / \mathrm{ha}$ ) & $0.63 \mathrm{a}$ & $0.70 \mathrm{~b}$ & $0.86 \mathrm{a}$ & $1.79 \mathrm{~b}$ & $0.32 \mathrm{a}$ & $1.42 \mathrm{~b}$ & $* *$ & $* *$ \\
\hline
\end{tabular}

\footnotetext{
${ }^{1}$ Means with different letters within the same season sub-column are different $(\mathrm{P}<0.01)$.

${ }^{2}$ Seasonal effect: level of significance ${ }^{*} \mathrm{P}<0.05$, ** $\mathrm{P}<0.01 ; \mathrm{NS}$ : non significant.

The herbage mass does not add up to leaf, stem and debris mass in some cases because the difference is represented by miscellaneous non gramineae species.
} 
TABLE 2. Herbage characteristics at the start and end of each grazing period of rotationally grazed tropical pastures for suckling Martinik ewes (S) in Guadeloupe according to pasture management, refusals mown (RM) vs. refusals remained (RR) and birth season.

\begin{tabular}{|c|c|c|c|c|c|c|c|c|}
\hline \multirow{2}{*}{$\begin{array}{l}\text { Season } \\
\text { Pasture management }\end{array}$} & \multicolumn{2}{|c|}{ Dry season } & \multicolumn{2}{|c|}{ Intermediate season } & \multicolumn{2}{|c|}{ Rainy season } & \multicolumn{2}{|c|}{ Seasonal effect } \\
\hline & SRM & SRR & SRM & SRR & SRM & SRR & SRM & SRR \\
\hline \multicolumn{9}{|c|}{ Herbage characteristics at the start of the grazing period } \\
\hline Pasture height (mm) & $61.80 \mathrm{a}^{1}$ & $103.60 \mathrm{~b}$ & $47.90 \mathrm{a}$ & $68.30 \mathrm{~b}$ & 99.60 & 103.20 & $* * 2$ & $* *$ \\
\hline Dry matter content (\%) & 24.90 & 27.50 & 28.10 & 27.10 & 17.70 & 22.10 & * & * \\
\hline Herbage mass $(\mathrm{t} \text { DM/ha })^{3}$ & $2.65 \mathrm{a}$ & $3.05 \mathrm{~b}$ & $2.38 \mathrm{a}$ & $3.82 \mathrm{~b}$ & $2.58 \mathrm{a}$ & $4.39 \mathrm{~b}$ & NS & $* *$ \\
\hline Leaf mass (t DM/ha) & 1.20 & 1.22 & $1.08 \mathrm{a}$ & $1.41 \mathrm{~b}$ & 1.16 & 1.36 & NS & NS \\
\hline Stem mass (t DM/ha) & 0.95 & 0.89 & $0.83 \mathrm{a}$ & $1.39 \mathrm{~b}$ & $1.00 \mathrm{a}$ & $1.62 \mathrm{~b}$ & NS & $* *$ \\
\hline Debris mass (t DM/ha) & $0.45 \mathrm{a}$ & $0.76 \mathrm{~b}$ & $0.44 \mathrm{a}$ & $0.96 \mathrm{~b}$ & $0.45 \mathrm{a}$ & $1.34 \mathrm{~b}$ & NS & $* *$ \\
\hline Leaf/stem ratio & 1.26 & 1.37 & $1.29 \mathrm{a}$ & $1.01 \mathrm{~b}$ & $1.16 \mathrm{a}$ & $0.84 \mathrm{~b}$ & NS & *** \\
\hline \multicolumn{9}{|c|}{ Herbage characteristies at the end of the grazing period } \\
\hline Pasture height (mm) & 57.60 & 57.40 & $41.00 \mathrm{a}$ & $62.00 \mathrm{~b}$ & $54.00 \mathrm{a}$ & $69.30 \mathrm{~b}$ & NS & $*$ \\
\hline Herbage mass (t DM/ha) & $1.34 \mathrm{a}$ & $2.45 \mathrm{~b}$ & $1.21 \mathrm{a}$ & $3.13 \mathrm{~b}$ & $2.41 \mathrm{a}$ & $4.05 \mathrm{~b}$ & $* *$ & *** \\
\hline Leaf mass (t DM/ha) & $0.15 \mathrm{a}$ & $0.48 \mathrm{~b}$ & $0.16 \mathrm{a}$ & $0.32 \mathrm{~b}$ & 0.50 & 0.49 & ** & *** \\
\hline Debris mass ( $\mathrm{t}$ DM/ha) & $0.59 \mathrm{a}$ & $0.93 \mathrm{~b}$ & $0.45 \mathrm{a}$ & $1.51 \mathrm{~b}$ & $0.57 \mathrm{a}$ & $1.42 \mathrm{~b}$ & * & *** \\
\hline
\end{tabular}

\footnotetext{
${ }^{1}$ Means with different letters within the same season sub-column are different $(\mathrm{P}<0.01)$.

${ }^{2}$ Seasonal effect: level of significance $* \mathrm{P}<0.05,{ }^{* *} \mathrm{P}<0.01$; NS: non significant.

The herbage mass does not add up to leaf, stem and debris mass in some cases because the difference is represented by miscellaneous non gramineae species.
} 
TABLE 3. Chemical composition of herbage $(\mathrm{g} / \mathrm{kg} D M)$ at the start and end of each grazing period of rotationally grazed tropical pastures for suckling Creole goats $(G)$ in Guadeloupe according to pasture management, refusals mown (RM) vs. refusals remained (RR) and birth season.

\begin{tabular}{|c|c|c|c|c|c|c|c|c|}
\hline \multirow{2}{*}{$\begin{array}{l}\text { Season } \\
\text { Pasture management }\end{array}$} & \multicolumn{2}{|c|}{ Dry season } & \multicolumn{2}{|c|}{ Intermediate season } & \multicolumn{2}{|c|}{ Rainy season } & \multicolumn{2}{|c|}{ Seasonal effect } \\
\hline & GRM & GRR & GRM & GRR & GRM & GRR & GRM & GRR \\
\hline \multicolumn{9}{|c|}{ Chemical composition at the start of the grazing period } \\
\hline Crude protein & 120.0 & 113.2 & 104.1 & 89.3 & 145.0 & 127.4 & $* 1$ & * \\
\hline Neutral detergent fiber & 685.4 & 717.7 & 732.5 & 739.1 & 713.0 & 742.2 & $* *$ & NS \\
\hline Acid detergent fiber & 337.2 & 365.3 & 361.4 & 376.6 & 368.0 & 377.1 & NS & NS \\
\hline Acid detergent lignin & $72.5 \mathrm{a}^{2}$ & $43.6 \mathrm{~b}$ & 46.6 & 50.0 & 68.1 & 65.0 & *** & * \\
\hline \multicolumn{9}{|c|}{ Chemical composition at the end of the grazing period } \\
\hline Crude protein & 87.5 & 89.1 & 76.8 & 75.2 & $112.1 \mathrm{a}$ & $79.0 \mathrm{~b}$ & NS & NS \\
\hline Neutral detergent fiber & 709.3 & 716.8 & 721.7 & 734.4 & 701.6 & 731.7 & NS & NS \\
\hline Acid detergent fiber & 358.1 & 376.7 & 363.7 & 378.1 & 368.3 & 373.0 & NS & NS \\
\hline Acid detergent lignin & 54.8 & 62.7 & 67.4 & 65.1 & 72.2 & 87.5 & NS & $*$ \\
\hline
\end{tabular}

${ }^{1}$ Seasonal effect: level of significance $* \mathrm{P}<0.05$, ${ }^{*} * \mathrm{P}<0.01$; NS: non significant.

${ }^{2}$ Means with different letters within the same season sub-column are different $(\mathrm{P}<0.01)$. 
TABLE 4. Chemical composition of herbage $(\mathrm{g} / \mathrm{kg} D M)$ at the start and end of each grazing period of rotationally grazed tropical pastures for suckling Martinik ewes (S) in Guadeloupe according to pasture management, refusals mown (RM) vs. refusals remained (RR) and birth season.

\begin{tabular}{|c|c|c|c|c|c|c|c|c|}
\hline \multirow{2}{*}{$\begin{array}{l}\text { Season } \\
\text { Pasture management }\end{array}$} & \multicolumn{2}{|c|}{ Dry season } & \multicolumn{2}{|c|}{ Intermediate season } & \multicolumn{2}{|c|}{ Rainy season } & \multicolumn{2}{|c|}{ Seasonal effect } \\
\hline & SRM & SRR & SRM & SRR & SRM & SRR & SRM & SRR \\
\hline \multicolumn{9}{|c|}{ Chemical composition at the start of the grazing period } \\
\hline Crude protein & 95.1 & 85.2 & 87.3 & 79.0 & 114.9 & 90.8 & $\mathrm{NS}^{1}$ & NS \\
\hline Neutral detergent fiber & 698.6 & 705.7 & 723.8 & 726.2 & 748.1 & 740.4 & * & * \\
\hline Acid detergent fiber & 348.5 & 345.9 & 334.9 & 349.3 & 367.6 & 372.6 & NS & NS \\
\hline Acid detergent lignin & 46.9 & 43.7 & 42.3 & 54.6 & 66.5 & 63.7 & * & * \\
\hline \multicolumn{9}{|c|}{ Chemical composition at the end of the grazing period } \\
\hline Crude protein & 67.0 & 67.2 & 72.8 & 58.0 & 89.9 & 59.0 & NS & NS \\
\hline Neutral detergent fiber & 723.7 & 706.4 & 697.8 & 728.1 & 712.8 & 727.5 & NS & NS \\
\hline Acid detergent fiber & 377.9 & 358.8 & 347.2 & 354.7 & 363.3 & 367.6 & NS & NS \\
\hline Acid detergent lignin & 62.4 & 63.0 & 57.7 & 61.4 & 58.5 & 72.3 & NS & NS \\
\hline
\end{tabular}

${ }^{1}$ Seasonal effect: level of significance ${ }^{*} \mathrm{P}<0.05,{ }^{*} \mathrm{P}<0.01$; NS: non significant. 
Figure 1 depicts the differences (expressed in percentage) between the control system and the "residuals mown" system throughout the year. For both small ruminant species, after the first season of production, herbage accumulation was $70 \%$ higher in the RR plots than in the $\mathrm{RM}$ and this difference was clearly related to differences in the debris proportion.

Mean forage NNI value was higher in the goat plots than in the sheep plots, $84 \%$ vs. $60 \%$, respectively (Figure 2 ). This index was higher $(\mathrm{P}<0.05)$ in the rainy season than in the other two seasons.

The mean daily forage allowance (Table 5) per head of dams was 1.83 vs. $2.93 \mathrm{~kg} \mathrm{DM}(\mathrm{P}<0.01)$ for the GRM vs. GRR plots, and 2.26 vs. $3.35 \mathrm{~kg}$ DM $(\mathrm{P}<0.01)$ for the SRM vs. SRR plots, respectively. In the $R R$ systems, regardless of species, lower $(\mathrm{P}<0.05)$ values were noted during the dry season than during the other two seasons. Growth traits (mean \pm s.e.) of the kids and lambs are presented in Table 5. Litter size and sex affected $(\mathrm{P}<0.01)$ all these variables. For both species, weaning took place at an average age of $81.4 \pm 3.6$ days. In Creole kids, the ADG adjusted for birthweight were $90 \pm 9 \mathrm{~g}$ and $85 \pm 8 \mathrm{~g}$, in GRM vs. GRR groups, respectively. Corresponding values in the Martinik sheep were $195 \pm 10 \mathrm{~g}$ and $197 \pm 10 \mathrm{~g}$, respectively. Pre-weaning ADG was lower $(\mathrm{P}<0.05)$ with RR than RM only during the intermediate season for kids and during the rainy season for lambs (Table 5).

\section{DISCUSSION}

The decrease in herbage mass induced by the removal of residues, varying with the type of grazer (62\% in goat plots and $48 \%$ in sheep plots) and with the season (about $65 \%$ of variation), was consistent with existing knowledge on stoloniferous grass physiology [see review of Cruz and Boval, (2000)]. In such plants, both leaves and stems are produced as aerial organs. Leaf tissue production appears to be dependant on the stolon internode elongation. The acceleration of internode elongation pushes each new leaf out of the sheath but subsequently it may serve to reduce the duration of the leaf elongation process. The leaf senescence occurs very early at the expense of larger leaves, whereas the new emerging leaves become progressively smaller. Thus net leaf elongation at a given growing point becomes negative and debris accumulations begin to be important. The ceiling leaf area index (LAI) of the sward is reached very early (even more rapidly when the nitrogen nutrition level is high).

However, according to the recent review of Hughes et al. (2001), results of experiments on the effect of residual herbage mass on subsequent pasture growth were inconclusive (with positive, negative 

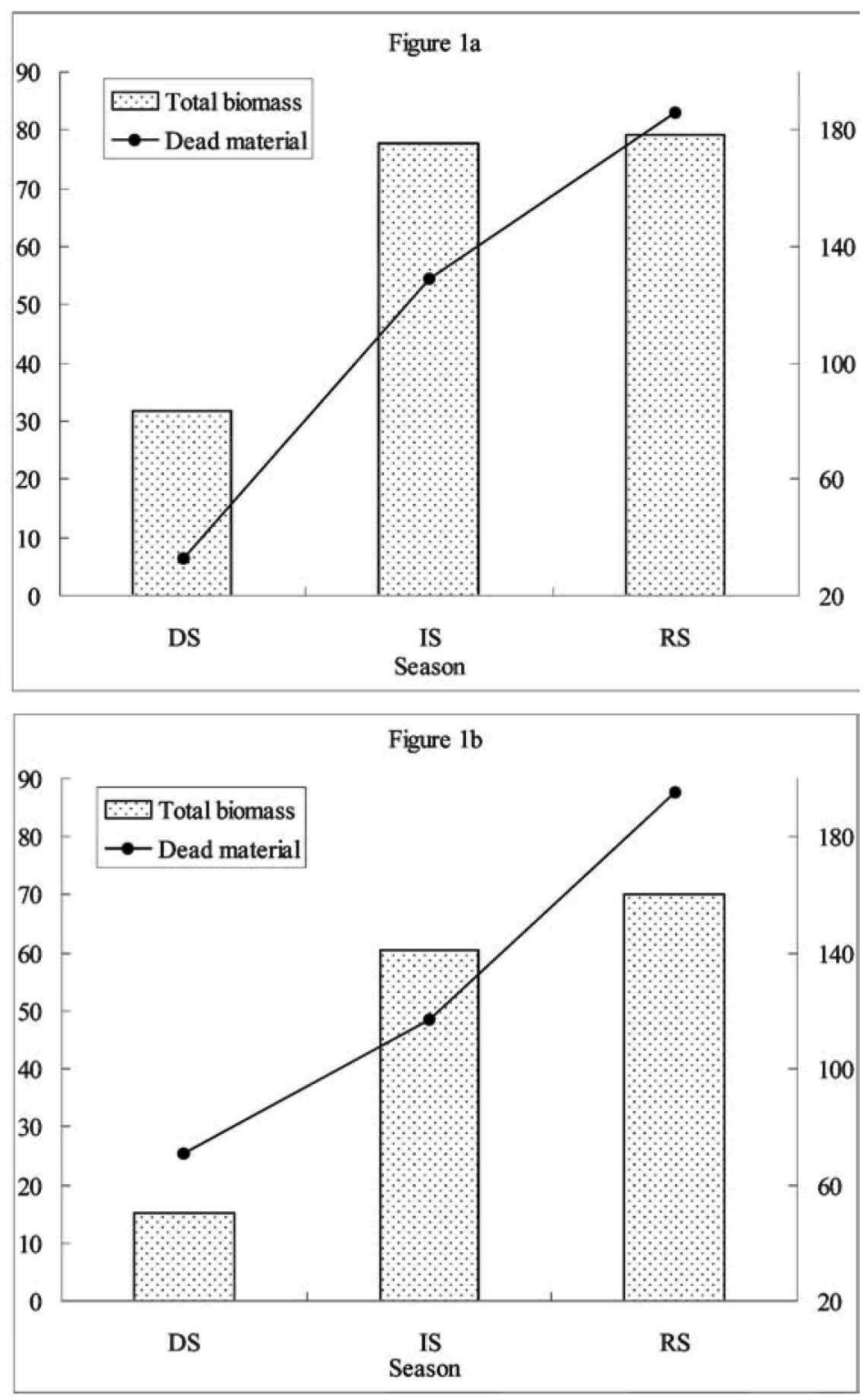

FIGURE 1. Difference of accumulation in total herbage biomass and in dead material biomass between residuals mown (RM) and residuals remained (RR) systems (RR is expressed as a fraction of RM) according to season of production (dry season, DS; intermediate season IS and rainy season, RS). Figure 1a in goat plots and Figure 1b in sheep plots. 


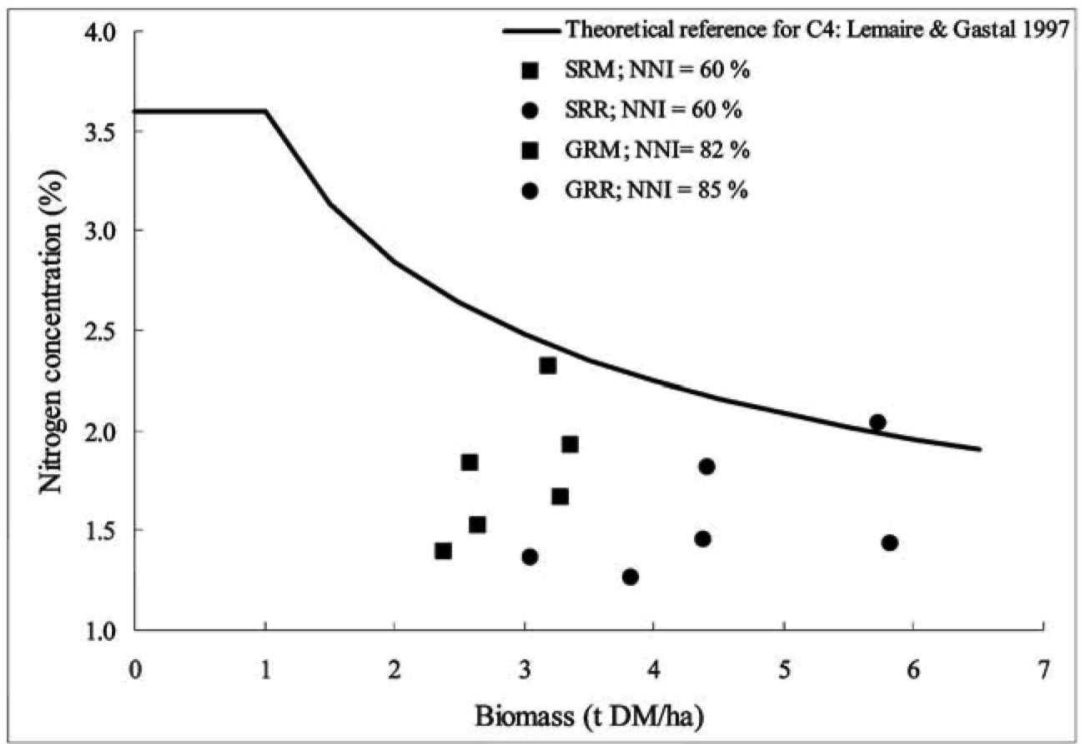

FIGURE 2. Relation between nitrogen concentration of herbage and total herbage biomass in $\mathrm{C} 4$ grasses and representation of nitrogen nutrition index (NNI) for goat (G) and sheep (S) plots according to pasture management system residuals mown (RM) vs. residuals remained $(\mathrm{RR})$ at the different seasons of production. NNIs were calculated as the ratio $(\times 100)$ between the observed plant nitrogen percentage and the critical plant nitrogen percentage as calculated by the theoretical equation.

and no effect being reported). It depended on the amounts of remaining residues (Hughes et al., 2001), or the defoliation height (HernándezGaray et al., 1999). In our repetitive system of mowing (RM systems), final height and herbage mass were almost nil (complete removal at 5 $\mathrm{cm}$ above ground) whereas the control systems were characterized by huge amounts of post-grazing residues (varying from 2.5 to $4.5 \mathrm{t} \mathrm{DM} /$ ha). Hughes et al. (2001) observed on New Zealand dairy farms that high post grazing residues had little effect on net herbage accumulation (NHA) rate. In our study the NHA was not assessed. According to Hernández-Garay et al. (1999) the NHA depended on the defoliation rate. From work on perennial ryegrass swards in New Zealand, these authors concluded that in defoliated swards, increasing defoliation severity increased energy loss and decreased the LAI that can be maintained. Because of this reduction in canopy leaf area, compensation between tiller density and size may operate to increase leaf mass. Thus it might be that in the RM systems, such a trade-off operated to influence positively and rapidly the herbage accumulation, as Velasco 
TABLE 5. Herbage allowance ( $\mathrm{gg} D M /$ dam/day) of rotationally grazed tropical pastures for suckling Creole goat, and Martinik ewes and pre-weaning average daily gain ( $g /$ day) of kids and lambs according to pasture management, refusals mown (RM) vs. refusals remained $(R R)$ and birth season.

\begin{tabular}{|c|c|c|c|c|c|c|c|c|}
\hline \multirow{2}{*}{$\begin{array}{l}\text { Variable } \\
\text { Pasture management }\end{array}$} & \multicolumn{2}{|c|}{ Dry season } & \multicolumn{2}{|c|}{ Intermediate season } & \multicolumn{2}{|c|}{ Rainy season } & \multicolumn{2}{|c|}{ Seasonal effect } \\
\hline & $\mathrm{RM}$ & $\mathrm{RR}$ & $\mathrm{RM}$ & RR & $\mathrm{RM}$ & $\mathrm{RR}$ & $\mathrm{RM}$ & $\mathrm{RR}$ \\
\hline \multicolumn{9}{|c|}{ Creole kids } \\
\hline Herbage allowance & $1.76 \mathrm{a}^{1}$ & $2.59 \mathrm{~b}$ & $1.92 \mathrm{a}$ & $3.41 \mathrm{~b}$ & $1.81 \mathrm{a}$ & $2.80 \mathrm{~b}$ & $\mathrm{NS}^{2}$ & $*$ \\
\hline Average daily gain ${ }^{3}$ & 103 & 98 & 96 & 90 & 72 & 68 & $*$ & ** \\
\hline $\mathrm{SE}^{4}$ & 8 & 8 & 8 & 7 & 7 & 7 & & \\
\hline Herbage allowance & $2.37 \mathrm{a}$ & $2.73 \mathrm{~b}$ & $2.12 \mathrm{a}$ & $3.41 \mathrm{~b}$ & $2.30 \mathrm{a}$ & $3.92 \mathrm{~b}$ & NS & $*$ \\
\hline Average daily gain ${ }^{3}$ & 183 & 178 & 209 & 208 & 192 & 205 & $*$ & $*$ \\
\hline $\mathrm{SE}^{4}$ & 9 & 10 & 9 & 9 & 8 & 10 & & \\
\hline
\end{tabular}

${ }^{1}$ Means with different letters within the same season sub-column are different $(\mathrm{P}<0.01)$.

${ }^{2}$ Seasonal effect: level of significance $* \mathrm{P}<0.05, * * \mathrm{P}<0.01 ; \mathrm{NS}$ : non significant.

${ }^{3}$ Data adjusted to birth weight.

${ }^{4} \mathrm{SE}$ standard error associated with Least Square Means. 
et al. (2001) have reported for Dactylis glomerata, under conditions in Mexico. A differential reaction of herbage to cutting vs. grazing could also explain the variations of biomass between RM and RR systems, as reported by Binnie and Chestnutt (1991). The ungrazed or partially grazed plants provided an important nucleus capable of more rapid regrowth than the more uniformly defoliated stubble of a cut sward. In fact the herbage accumulation in the RR systems was related to the stem and debris accumulation (120\% more than in RM on average).

There was greater herbage accumulation over three seasons in goat than in sheep pastures, and in the control system than in the mown plots. Thus, the relative difference in favor of goat over sheep pastures was for stem biomass, $64 \%$ (2.13 vs.1.30 t DM/ha) under RR, and 32\% (1.3 vs. $0.93 \mathrm{t} \mathrm{DM} / \mathrm{ha}$ ) under RM; for leaf biomass, $26 \%$ (1.69 vs. $1.34 \mathrm{t}$ $\mathrm{DM} / \mathrm{ha}$ ) under RR and 6\% (1.21 vs. 1.15 t DM/ha) under RM. As reported for another tropical grass, Dichanthium, there was a threshold NNI value of $70 \%$, under which stolon growth was inhibited by nitrogen deficiency (Cruz and Boval, 2000). An NNI equal to $82 \%$ or $85 \%$ in goat pastures probably induced higher stolon development than in the sheep plots having a lower NNI value of $60 \%$. Another possibility worthy of consideration, although not assessed in our study, is that as the defoliation patterns are determined by the species of grazer, the forage regrowth patterns are influenced by the animal interacting with the pasture. This influence has been well documented by Penning et al. (1996) comparing the effects of sheep and goat grazing on sward composition, and by Wright et al. (2001) comparing the effects of sheep and cattle grazing on sward structure.

The herbage biomass values under the control systems (GRR, $5.0 \mathrm{t}$ $\mathrm{DM} / \mathrm{ha}$ and SRR, 3.8 t DM/ha) were similar to those obtained in previous studies with goats, $6.0 \mathrm{t} \mathrm{DM/ha} \mathrm{(Alexandre} \mathrm{et} \mathrm{al.,} \mathrm{1997),} \mathrm{and} \mathrm{with}$ ewes, $4.0 \mathrm{t} \mathrm{DM} /$ ha (Mahieu et al., 2002), although in the present experiment the nitrogen supply was about fifty percent less (data were recalculated to permit comparison at the same age of regrowth). Thus the amount of fertilizer input could be decreased provided that the soil characteristics so warrant.

In the RR swards, the seasonal differences in herbage mass were consistent with those of other reports on the growth of Digitaria decumbens in grazed swards (Cruz et al., 1989; Hacker and Evans, 1992; Alexandre et al., 1997; Mahieu et al., 1997) or cut swards (Salette and Chenost, 1971; Crespo, 1985; Minson, 1990; Gargano and Adúriz, 2001). No seasonal effect was observed in the RM systems, in which the severe and repetitive defoliation system may have influenced the regrowth pattern. Regardless of the season, the daily DM accumulation was rather similar, at about 111 and $91 \mathrm{~kg} \mathrm{DM} / \mathrm{ha}$. 
The herbage debris fraction was far lower in the RM than in the RR system, as expected. The leaf/stem ratio when the animals were let into the paddocks was improved in the RM swards over that of the RR, with a more pronounced effect in the sheep than in the goat plots. The composition of a grazed multispecies sward results from the competitive interactions between species and the environmental conditions (principally light and nutrients), which are modified by the structure of species, their growth strategy and the degree of defoliation (Westoby, 1999). As stem elongation rate, leaf appearance rate and elongation are dependant, these may be very well combined processes, as reported by Hernández-Gray et al. (1999) for turfed grasses, and by Cruz and Boval (2000) for stoloniferous plants. Probably after a complete defoliation an equilibrium is reached leading to a more "turf-like" sward in RM than in the RR system. Moreover, the structure of the sward is influenced by the species of grazer (Penning et al., 1996; Wright et al., 2001). The ewes grazed more uniformly than the goats.

The leaf/stem ratio observed in the control system was higher than in previous studies, 0.70 in goat experiments (Alexandre et al., 1997), or 0.96 with ewes (Mahieu et al., 2002). This trait depends on the forage age of regrowth, which varied from one experiment to another. In Digitaria decumbens swards without growing limitations (Cruz et al., 1989) the net leaf accumulation ends suddenly after three weeks of canopy growth, after which time the accumulation of stolon rapidly exceeds the accumulation of green leaf material and the leaf/stem ratio of the forage rapidly declines. In addition, leaf/stem is a result of the effect of nitrogen fertilization effects on stolon elongation. Under intensive conditions (high nitrogen fertilization and irrigation), which characterized our previous studies, growth, and thus maturity of the forage, was accelerated. Changes in forage maturity were accompanied by increases in yield and in proportion of stems, and decreases in the proportion of leaf, as described by Minson (1990). Under intensive grazing systems where post-grazing residues are not controlled, accumulation of stolons rapidly exceeds accumulation of green leaf material and this deterioration in quality is emphasized by the accumulation of dead materials. In the present study, the difference in herbage accumulation, between the RR and RM plots, was clearly related to the debris proportion.

The morphological composition varied according to the season as reported previously (Cruz et al., 1989; Hacker and Evans, 1992; Sanderson et al., 1999; Velasco et al., 2001). The chemical composition of forage on offer was close to that of results previously reported on tropical grasses (Aumont et al., 1995; Archimède et al., 2000). However, the absence of seasonal effects on the chemical composition observed in 
the present experiment is not in agreement with the conclusions of $\mathrm{Au}$ mont et al. (1995) and Gargano and Adúriz (2001). At the end of the grazing period, the $\mathrm{CP}$ content of the herbage refusals was about 81 to $61 \mathrm{~g} / \mathrm{kg}$ DM in goat and sheep plots, respectively. These values together with levels of post-grazing residuals (3.6 and $3.2 \mathrm{t} \mathrm{DM/ha,} \mathrm{respectively)}$ suggest possible utilization of this material by low-requirement animals, such as under the leader-follower system studied by Hacker and Evans (1992) and Alexandre et al. (1997), or for use with other herbivores as studied by Mahieu et al. (1997, 2002) and Wright et al. (2001).

The high level of ADG, $88 \mathrm{~g}$ and $196 \mathrm{~g}$ for kids and lambs, respectively, would indicate that feeding conditions were adequate. The herbage allowances were at a satisfactory level even in the RM systems. This latter reached about 1.5 times more than the daily DM intake of suckling goats, $88 \mathrm{~g} \mathrm{DM} / \mathrm{kg}^{0.75} \mathrm{LW}$ (data recalculated from Morand-Fehr and Sauvant, 1988), and 1.2 times more than the daily DM intake of suckling ewes, $100 \mathrm{~g} \mathrm{DM} / \mathrm{kg}^{0.75} \mathrm{LW}$ (data recalculated from Bocquier et al., 1988). In the RR system, the herbage allowances reached 2.0 to 2.4 times more than the daily DM intake of suckling ewes and goats, respectively. Although there was a high stocking rate, the forage biomass and composition would allow a high degree of selectivity for these high-requirement animals and consequently adequate intake and production levels.

\section{CONCLUSION}

The elimination of post-grazing residues under intensive grazing systems with small ruminants improved the sward structure and reduced the forage biomass on offer. As goats refused more herbage than ewes, and because of the high nitrogen status of the goat plots, the difference GRM vs. GRR was more pronounced than that of SRM vs. SRR plots. Because of the biology of stoloniferous $\mathrm{C} 4$ tropical grasses, it is difficult to manage them to provide the type of leafy sward necessary for high-yielding livestock. Such systems require intensive grazing and therefore high internal parasite risk as well as high inputs of nitrogen fertilizer. Moreover, stolon development shows seasonal variations which require a seasonal adjustment of stocking rate.

Although the elimination of post-grazing residues was positive in regard to the pasture characteristics, it did not increase growth rate of the suckling offspring in comparison to that of the control system. Indeed the forage characteristics in the two systems were not limiting factors since forage availability and chemical composition were at satisfactory levels. Evidently the sward characteristics allowed a high degree of selectivity by these high-requirement animals and consequently 
adequate intake and production levels. The $\mathrm{CP}$ content of the herbage refusals of about 81 and $61 \mathrm{~g} / \mathrm{kg} \mathrm{DM}$ in goat and sheep plots, together with the levels of post-grazing residuals (3.6 and $3.2 \mathrm{t} \mathrm{DM/ha,} \mathrm{respec-}$ tively), suggests their possible utilization by low-requirement animals.

The elimination of post-grazing residues by mowing tested in this work was experimental. Its high cost makes it commercially impractical. Rather, we recommend development of new grazing systems in which post-grazing residues would be eliminated by associated herbivores instead of by mowing. However, one of the goals achieved in this work was a reduction of input (50\% less fertilizer and no feed supplements) while maintaining high productivity.

\section{LITERATURE CITED}

Alexandre, G., G. Aumont, J. Fleury, O. Coppry, P. Mulciba and A. Nepos, 1997. Production semi-intensive au pâturage de caprins à viande en zone tropicale humide: Le cas des cabris Créoles sur pangola (Digitaria decumbens) en Guadeloupe. Prod. Anim. 10:43-53.

Archimède, H., M. Boval, G. Alexandre, A. Xandé, G. Aumont and C. Poncet, 2000. Effect of regrowth age on intake and digestion of Digitaria decumbens consumed by Black-belly sheep. Anim. Feed Sci. Technol. 87:153-162.

Aumont, G., I. Caudron, G. Saminadin and A. Xandé, 1995. Sources of variation in nutritive values of tropical forages from the Caribbean. Anim. Feed Sci. Technol. 51:1-13.

Aumont, G., R. Pouillot, R. Simon, G. Hostache, N. Barré, and H. Varo, 1997. Parasitisme digestif des petits ruminants dans les Antilles françaises. INRA Prod. Anim. 10:79-90.

Baumont, R., S. Prache, M. Meuret and P. Morand-Fehr, 2000. How forage characteristics influence behaviour and intake in small ruminants: A review. Cah. Options Méditerr. 52:11-25.

Binnie, R. C. and D. M. B. Chestnutt, 1991. Effect of regrowth interval on the productivity of swards defoliated by cutting and grazing. Grass Forage Sci. 46:343-350.

Bocquier, F., M. Theriez, S. Prache and A. Brelurut, 1988. Alimentation des ovins. Alimentation des bovins, ovins et caprins. R. Jarrige (ed.), pp. 249-271.

Cardoso, E. L., S. M. A. Crispim and C. A. G. Rodrigues, 2001. Aboveground standing erop of an ungrazed Elyonurus muticus grassland under annual burning in the Pantanal, Brazil. Proc. 19th Inter. Grassland Congr. San Pedro, Sao Paulo, Brazil, pp. 816-817.

CIAT (Centro Internacional de Agricultura Tropical), 1985. Evaluación de pasturas con animales. Memorias de una reunión de trabajo. C. Lascano and E. Pizarro, (eds.). Cali, Colombia. 292 pp.

Crespo, G., 1985. Variation in the response of tropical pastures to nitrogenous fertilizers throughout the year. 2. Pangola (Digitaria decumbens Stent) grass with irrigation. Cuban J. Agric. Sci. 19:307-32.

Cruz, P., G. Alexandre and H. Baudot, 1989. Cinétique de la croissance foliaire et stolonifere d'un peuplement de Digitaria decumbens au cours de la repousse. Proc. 16th Inter. Grassland Congr. Nice, France, pp. 499-500.

Cruz, P. and M. Boval, 2000. Effect of nitrogen on some morphogenetic traits of temperate and tropical perennial forage grasses. pp. 151-168 In: Grassland ecophysiology and grazing ecology. G. Lemaire, J. Hodgson, A. De Moraes, P. C. Carvalho and C. Nabinger (eds.), University of Cambrigde, UK. 
Cruz, P. and G. Lemaire, 1995. Diagnosis of the nitrogen status of grass stands. Principles and uses of the dilution curves method. In: 5th Australian Tropical Pastures Conference, Atherthon, Australia, 27-30 06/95. Tropical Grasslands, 1996, 30(1), p. 166.

Daget, P. and J. Poissonet, 1971. Méthode d'analyse de la végétation des pâturages. Critères d'application. Ann. Agron. 22:5-41.

FAO, 2001. FAOSTAT Statistics Database on-Line-Agriculture. FAO/WAICENT. http:/ lapps.fao.org (May, 2001).

Fournet, J., 1978. Flore illustrée des phanérogames de Guadeloupe et de Martinique. Editions INRA. $1654 \mathrm{pp}$.

Gargano, A. O. and M. A. Adúriz, 2001. Diferencias estacionales en rendimiento y calidad de Digitaria eriantha cv. Irene. Mem. XVII Reunión Asoc. Latinoamericana Prod. Anim. La Habana, Cuba, pp. 100-103.

Hacker, J. B. and T. R. Evans, 1992. An evaluation of the production potential of six tropical grasses under grazing. 1. Yield and yield components, growth rates and phenology. Aust. J. Exp. Agric. 32:19-27.

Heringer, I. and A.V.A. Jacques, 2001. Burning and management alternatives on forage accumulation and floristic composition of a native pasture. Proc. $19^{\text {th }}$ Inter. Grassland Congr. San Pedro, Sao Paulo, Brazil, pp. 827-828.

Hernández-Garay, A., C. Mathew and J. Hodgson, 1999. Tiller size/density compensation in perennial ryegrass miniature swards subject to different defoliation heights and a proposed productivity index. Grass Forage Sci. 54:347-356.

Hughes, F. P., P. N. P. Mathews and C. Mathew, 2001. The effects of post-grazing sward condtions on herbage accumulation in winter and spring. Proc. 19th Inter. Grassland. Congr. San Pedro, Sao Paulo, Brazil, pp. 824-825.

Humphreys, L. R., 1991. Tropical pasture utilization. 1st ed. Cambridge University, Great Britain. 206 pp.

Lemaire, G. and F. Gastal, 1997. N uptake and distribution in plant canopies. pp. 3-43 In: G. Lemaire (ed). diagnostic of $\mathrm{N}$ status in crops. Advanced series in Agricultural Sciences. Springler-Verlag, Berlin.

Mahieu, M., G. Alexandre, M. Boval, H. Archimède and G. Aumont, 2002. Pâturage alternatif de bovins et d'ovins. Une utilisation plus efficace du pâturage en zone tropicale humide. In: 38th Annual Congress of Caribbean Food Crops Society, Trois Ilets Martinique, 1-5/07/02, $4 \mathrm{pp}$.

Mahieu, M., G. Aumont, Y. Michaux, G. Alexandre, H. Archimède, M. Boval and M. Thériez, 1997. Lassociation d'ovins et des bovins sur prairies irriguées en Martinique. Prod.Anim. 10:55-65.

Minson, D. J., 1990. Forage in ruminant nutrition. Academic Press, Inc., New York. 483 pp.

Morand-Fehr, P. and D. Sauvant, 1988. Alimentation des ovins. pp. 282-302. In: Alimentation des bovins, ovins et caprins. R. Jarrige (ed.).

Penning, P. D., R. H. Johnson and R. J. Orr, 1996. Effects of continuous stocking with sheep or goats on sward composition and animal production from a grass and white clover pasture. Small Ruminant Res. 21:19-29.

Phillips, M. L. and I. P. Campbell, 1998. Improved lamb growth rates from winter cleaning of pastures. Anim. Prod. Aust. 22:307.

Salette, J. E. and M. Chenost, 1971. Intensification de la production fourragère en milieu tropical humide et son utilisation par les ruminants.. Colloque Internat. Pointe-à-Pitre, Guadeloupe (FWI). 266 pp.

Sanderson, M. A., P. Voigt and R. M. Jones, 1999. Yield and quality of warm-season grasses in central Texas. J. Range Manage. 52:145-150.

SAS, 1989. Statistical Analysis Systems user's guide (6th ed.). SAS Institute, Inc., Cary, NC. $151 \mathrm{pp.}$ 
Van Soest, P. J., J. B. Robertson and B. A. Lewis, 1991. Methods for dietary fiber, neutral detergent fiber and non starch polysaccharides in relation to animal nutrition. J. Dairy Sci. 74:3583-3597.

Velasco, Z. Ma. E., A. Hernández-Garay, V. A. González-Hernández, P. J. Pérez and H. Vaquera, 2001. Dinámica de crecimiento, rendimiento y calidad de forraje de Dactylis glomerata L. en respuesta a la defoliación. Mem. XVII Reunión Asoc. Latinoamericana Prod. Anim. La Habana, Cuba. pp. 77-79.

Westoby, M., 1999. The LHS strategy scheme in relation to grazing and fire. Proc. VIth Int. Rangeland Cong. Townsville, Australia 2:893-896.

Wright, I. A., J. R. Jones and A. J. Parsons, 2001. Effects of grazing by sheep or eattle on sward structure and subsequent performance of weaned lambs. Grass Forage Sci. 56:138-150. 